\title{
DOES EXTERNAL DEBT CONTRIBUTE TO MALAYSIA ECONOMIC GROWTH?
}

\author{
Siti Nurazira Mohd Dauda, Abd Halim Ahmad ${ }^{b}$, W.N.W. Azman-Sainic \\ ${ }^{a}$ Senior Lecturer, PhD, UniversitiSains Islam Malaysia, Faculty of Economics and Muamalat, 71700 Nilai, Negeri Sembilan, \\ Malaysia, nurazira@usim.edu.my. \\ ${ }^{b}$ Lecturer, MSc, Universiti Utara Malaysia, College of Business, 06010 Sintok, Kedah Darul Aman, Malaysia, \\ abd.halim@uum.edu.my. \\ 'Associate Professor, PhD, Universiti Putra Malaysia,Department of Economics, Faculty of Economics and Management, \\ 43400 Serdang, Selangor, Malaysia, wazman@putra.upm.edu.my.
}

\section{ARTICLE INFO}

Article data:

- Received: 20 January 2012

- Accepted: 14 May 2012

JEL classification: F43, F34, C32, O40

Keywords:

- Economic growth

- International economics

- External debt

- Malaysia

\section{ABSTRACT}

This paper analyzes the contribution of external debt to Malaysia's economic growth. To investigate whether the external debt has contributed to the economic growth in the long run, the growth model is tested by applying the Autoregressive Distributed Lag (ARDL) bound test. In addition, the existence of the threshold effect is examined to estimate the optimal level of external debt. The empirical results reveal that the accumulation of external debt is associated with an increase in Malaysia's economic growth up to an optimal level, and an additional increase of external indebtedness beyond the level has inversely contributed to the Malaysian economy.

Reference to this paper should be made as follows: Mohd Daud, N.; Halim Ahmad, A; Azman-Saini, W.N.W. 2013. Does External Debt Contribute to Malaysia Economic Growth?: Ekonomska istraživanja - Economic Research 26(2): 346-363. 


\section{INTRODUCTION}

In recent decades, literature on economic growth and its determinants has attracted considerable attention. However, studies conducted to examine the impact of external debt on economic growth are still lagging behind, leading to ambiguous answers. ${ }^{1}$ The increasing level of the stock of external debt has raised concerns about whether the external borrowing could help to boost economic growth or whether it could become a burden that future generation would have to pay for. In addition, the role of external debt in economic growthof developing countrieshas been questioned since there has been a high incidence of default, low economic growth and high levels of poverty, all of which are associated with high stocks of external debt. Furthermore, the uncertainties about country external debt sustainability position as well as whether countries are already trapped in the debt-overhang situation have underlined the importance of analyzing this issue.

Due to scarce resources in domestic economies, external debt has become one of the important sources of domestic capital. In particular, the dual-gap theory, that explains the savings gap and foreign exchange gap, has highlighted the motivation behind the introduction of external debt to a growth model. The savings gap and foreign exchange gap indicate that there are inadequate and insufficient resources to support the expected level of growth in the economy, revealing the role of external borrowings. Thus, the role of external borrowing in economic growth has been discovered even though it depends on the two gaps of either savingsinvestment or import-export. The foreign borrowing will increase until the gaps are narrowed and the expected marginal product of capital is equivalent to the marginal cost of funds.

Malaysia, as a small open economy that formulates and implements a prudent debt management policy, has shown an increasing pattern of total outstanding external debt. The tremendous increment has reached around 406.5 percent within 20 years, which highlighted issue on the usability of external debt to boost domestic economy. Furthermore, with high level of external debt, country would possibly increase the probability of being default. Does this development provide a good overview to attract investors from abroad to invest in the Malaysian economy? The answer would depend on the contribution of external debt to the economy, or the sustainability of the external position. If external debt has been efficiently allocated to domestic investment it could, in return, generate economic growth in the long run, implying that Malaysia's external debt position is sustainable. Furthermore, having the benefit of economic growth could also improve the capability of servicing the debt without crowding out the country's investment. On the other hand, if a country were to experience an adverse impact from its external borrowing, it would affect the investor's confidence since the debt would not have been productively channeled into investment or economic growth (Clements, Bhattacharya and Nguyen, 2003; Chowdhury, 2001; Mohamed, 2005; Wijeweera, Dollery and Pathberiya, 2005; Sen, Kasibhatla and Steward, 2007). As a result, with high levels of indebtedness, countries would not be able to generate more economic growth and would fail to repay their debts.

\footnotetext{
${ }^{1}$ Total external debt is defined as, at any given time, the outstanding amount of those actual current and non-contingent liabilities that require payments of principal and/ or interest by the debtor at some point in the future and that are owed to non-residents by residents of an economy (International Monetary Fund, 2003).
} 
At the other end of the spectrum, debt repayment has been used as a signaling device to reveal the competence of the government and can display the fundamentals of the country's economy (Sandleris, 2008). Moreover, the ability to repay debt is closely related to Malaysia's sovereign debt rating (probability of default) as well as the future borrowing opportunities. Risk of default, rescheduling and arrears are likely to increase the volatility of future inflows and additional lending, while access to capital markets depends on the perceived sustainability (Gunning and Mash, 1998). As such, any negative and uncertain elements in Malaysia's external position would possibly delay any foreign investment into the country.

As has been explained by the capital market imperfection, there is no effective mechanism to prevent borrowers from being in default to the lenders. Even with a high level of indebtedness where debt service could "crowd out" investment or, to a lesser extent, cause stagnant or declining economic growth, most of the developing countries such as Malaysia have tried their best not to default. ${ }^{2}$ Being either in default or in a debt-overhang situation is not the best solution for a country to maintain a sustainable position. Thus, an analysis of the relationship between external debt and economic growth could give us some intuition as to whether Malaysia has been benefiting from external borrowing over the past 20 years. This could also give a signal about the effectiveness of debt management policies in Malaysia. In other words, by considering the findings of this paper, governments could formulate policies that could prevent countries from being default or in a debt-overhang situation.

The objective of this paper is to analyze the debt-growth nexus, particularly for Malaysia. This paper provides evidence on the "disincentive effects" of high debts, due to the debt-overhang and macroeconomic instability, as well as liquidity constraint that could be referred to adverse effect of debt service on investment and growth. Furthermore, this paper is also concerned with the importance of the optimal level of external debt holding. This analysis is profound since any results found from the linkages between the external borrowing and economic growth would be useful for policy formulation. Regardless of whether there is a positive or negative relationship between external debt and economic growth, the non-linear relationship of debt and growth is important for providing an optimal level or threshold for a country to manage its debt position. Moreover, this paper could give an indirect signal to creditors on a country's ability to service its debt in the future.

This paper is distinct from other research in several aspects. This paper contributes to the small but growing body of empirical literature on the debt-growth nexus. To the best of our knowledge, only a few and inconclusive empirical studies have been carried out to determine whether external debt matters for Malaysia's economic growth. Moreover, this paper also investigates the potential of the non-linear relationship between external debt and economic growth (Laffer curve relationship). Thus, this study attempts to fill this gap in the literature. The paper is structured as follows.

\footnotetext{
${ }^{2}$ According to Borensztein and Panizza (2008), exclusion from the international capital market for future borrowing, international trade exclusion costs, costs to the domestic economy through the financial system and political costs to the authorities are among the cost that country potentially incur in the event of default.
} 
An overview of external debt and economic growth in Malaysia is presented in section II. The next section reviews the theoretical and empirical literature on the debt-growth model. Section IV outlines the data and methodology while the empirical results are presented in section $\mathrm{V}$, and section VI concludes the paper.

\section{EXTERNAL DEBT AND ECONOMIC GROWTH IN MALAYSIA}

Figure 1 shows the Malaysia's total outstanding of external debt since the early 1990s. The total outstanding of external debt has shown an increasing and tremendous upward pattern since the year 1990. As at the end of 2009, Malaysia's total outstanding external debt was recorded at RM233,136 million (or USD67.7 million), which is equivalent to 35.3 percent of Gross National Income (GNI) (Central Bank of Malaysia, 2009). ${ }^{3}$ The drastic increase in the external debt accumulation is during the first quarter of 1997 with 11.3 percent growth and 15.2 percent growth in second quarter of 2008. In addition, as at end of Q4 2009, the debt service amounted at 6.8 percent which indicates that Malaysia has used 6.8 times of its revenue to service its external debt.

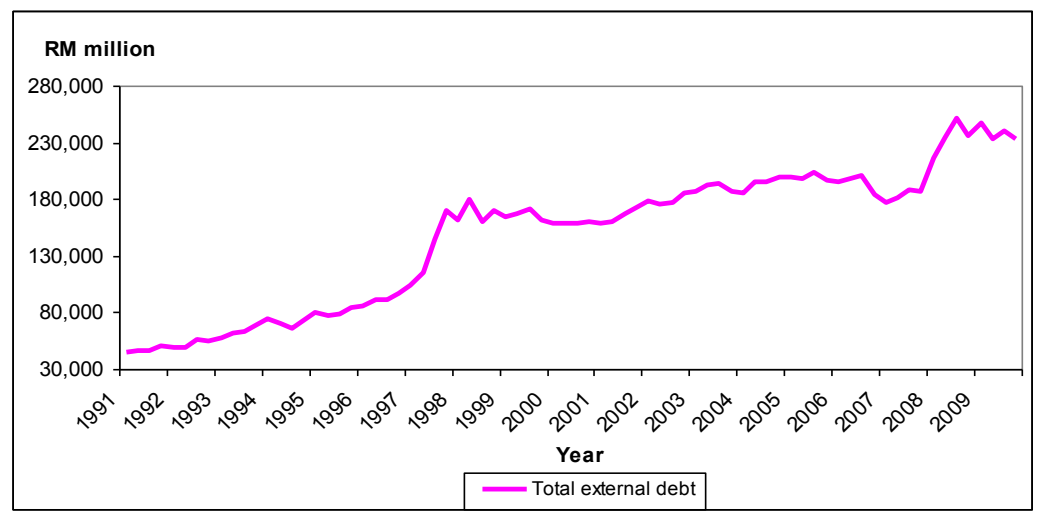

\section{FIGURE 1. TOTAL OUTSTANDING EXTERNAL DEBT OF MALAYSIA}

\section{Source. Central Bank of Malaysia, Monthly Bulletin}

In addition, Table 1 provides details on the compositions of Malaysia's total outstanding external debt for the period 1991 to 2009. The composition of Malaysia's external debt position shows a stable pattern over the period. Malaysia's external debt profile continued to be skewed towards a longer maturity structure with medium- and long-term debt accounting for 76.96 percent of total external debt over the period from 1991 to 2009.

\footnotetext{
${ }^{3}$ Malaysia has revised its external debt position in 2005 to be in line with the Balance of Payment manual (BPM5) by the International Monetary Fund (IMF) which classifies offshore entities (Labuan International Financial Offshore Financial Centre) in an economy as residents for compilation of external data, including external debt data.
} 
The external borrowing held by the Non-Financial Public Enterprises (NFPE thereafter) and private sector accounted for the largest portion of Malaysia's external debt, while the federal government debt remains low at an average of 19 percent.

TABLE 1 - THE COMPOSITIONS OF EXTERNAL DEBT

\begin{tabular}{|c|c|c|c|}
\hline & \multicolumn{3}{|c|}{ In million (Ringgit Malaysia) } \\
\hline & 1991Q1-2009Q4 & 1991Q1-1999Q4 & 2000Q1-2009Q4 \\
\hline Total external debt & 148,357 & 97,402 & 194,217 \\
\hline Long-term debt ${ }^{1}$ & 114,171 & 76,207 & 148,339 \\
\hline Federal government & 21,743 & 16,805 & 26,187 \\
\hline NFPE & 44,595 & 27,679 & 59,820 \\
\hline Private sector & 47,833 & 31,723 & 62,332 \\
\hline \multirow[t]{3}{*}{ Short-term debt } & 34,186 & 21,195 & 45,878 \\
\hline & \multicolumn{3}{|c|}{ As percentage of total external debt } \\
\hline & 1991Q1-2009Q4 & 1991Q1-1999Q4 & 2000Q1-2009Q4 \\
\hline Long-term external debt & 76.96 & 78.24 & 76.38 \\
\hline Federal government & 19.04 & 22.05 & 17.65 \\
\hline NFPE & 39.06 & 36.32 & 40.33 \\
\hline Private sector & 41.90 & 41.63 & 42.02 \\
\hline Short-term debt & 23.04 & 21.76 & 23.62 \\
\hline
\end{tabular}

Source: Monthly Bulletin Statistics, Central Bank of Malaysia

On the other hand, the Malaysian economy has recorded constant growth over the past three decades with several fluctuations in the economy as depicted in Figure 2. As a small open economy, Malaysia is sensitive to any fluctuation in international market and suffered a contraction in GDP growth due to the contagion and spillover effect from the external factors.

Descriptively, it shows that the growth in accumulation of external debt is higher than the growth in country economic growth. Furthermore, the information on the increasing trend and stable compositions of the external debt hold by all sectors has led to the question of whether Malaysia has benefited from the decision to borrow from abroad. 


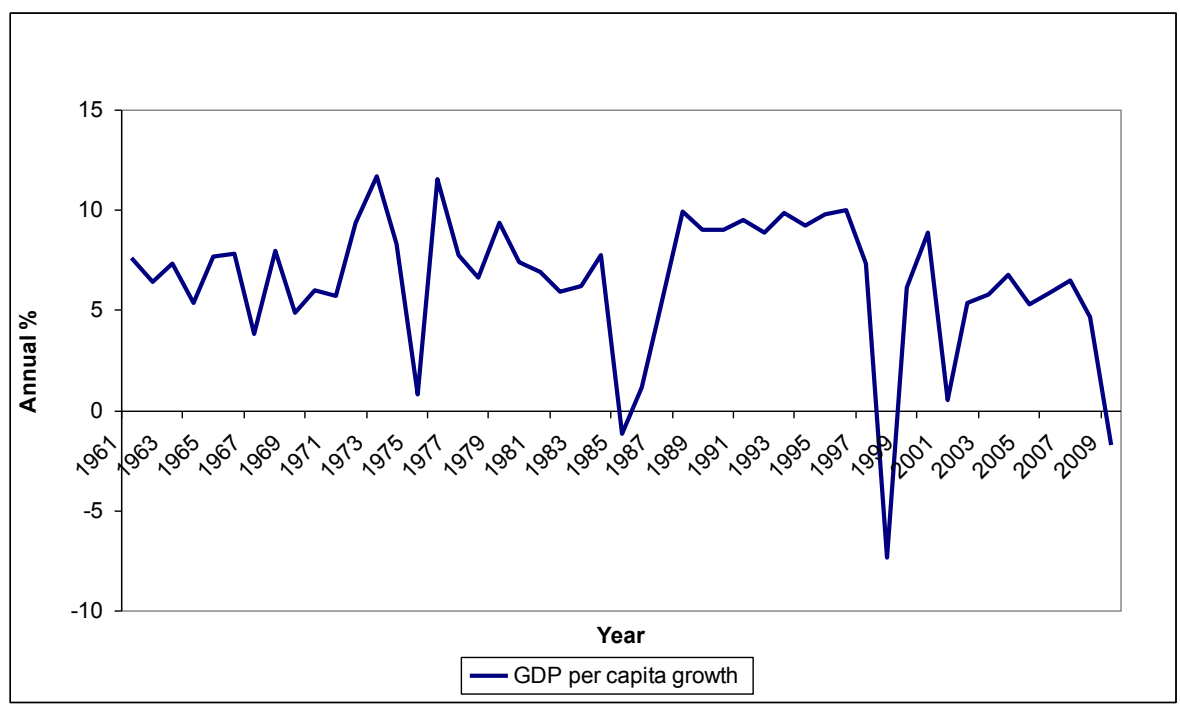

FIGURE 2. MALAYSIA ECONOMIC GROWTH, 1960-2009

Source. WDI, World Bank

\section{LITERATURE REVIEW}

In the neoclassical growth theory developed by Solow-Swan (1956), the domestic saving financing the aggregate investment with labour-augmenting technological change is exogenous in determining the equilibrium growth of per capita output. However, the growth model is feasible in the closed economy where there is no interaction with the rest of the world. In addition, Mankiw, Romer and Weil (1992) extend the Solow-Swan model to include human capital in the growth model by retaining the assumption of constant returns to scale in all inputs (diminishing returns to physical and human capital). Relatively speaking, small changes in resources devoted to physical and human capital may lead to large changes in output per worker. In the era of globalization, the interdependence among countries in the world through trade and capital flow has inspired Otani and Villanueva (1989), Agenor (2000), Villanueva (2003), and Villanueva and Mariano (2007) to develop a growth model for the open economy that incorporates a global capital market role. Krugman (1988) defines debt-overhang as a situation in which the expected repayment of external debt falls short of the contractual value of the debt. In addition, with the high level of debts having adverse effects on economic growth, a country would be faced with the high probability of experiencing the debt-overhang problem. Moreover, if there is some likelihood that, in the future, debt will be larger than the country's repayment ability the expected debt-service cost will discourage further domestic and foreign investment (Pattilio, Poirson and Ricci, 2002). In other words, large debt burdens squeeze investments because returns are discounted through debt service payment by foreign creditors. Furthermore, high debts have a negative impact on the rate of investment and economic growth because of disincentive, cash flow and moral hazard effects (Claessens, Detagiache, Kanbur and Wickham, 1997).

However, at a reasonable level of foreign borrowing, external debt could have a positive impact on investment and growth. The "Laffer Curve" describes the relationship between the face value of debt and investment. If the outstanding debt increases beyond a threshold level, the expected repayment begins to fall as a consequence of adverse effect. In other words, on the 
upward-sloping curve or 'good' section the implication is that an increase in the face value of debt is associated with an increase in expected repayment up to a threshold level. Along the 'bad' section of the "Laffer Curve", an increase in the face value of debt reduces expected payment.

A high-level stock of indebtedness and low level of investment in the 1980s by several Latin America countries has inspired Cohen (1995) to analyze whether the high debt stock could be the best predictor of the low level of investment rate. However, large debtors do not expect to service their debt, thus investment should not be crowded out. Surprisingly, the impact of debt flows (debt service) could affect economic growth by crowding out private investment or altering the composition of public spending. Higher debt service can raise the government budget deficit, thus reducing the public savings. This in turn may either raise interest rates or crowd out credit available for private investment, dampening economic growth (Clements, Bhattacharya and Nguyen, 2003). Higher debt service payments can also have adverse effects on the composition of public spending by shrinking the amount of resources available for infrastructure and human capital, with a negative effect on growth.

Over the past decades, academics and policy-makers have shown consistent interest in and have made efforts to investigate and develop the theory on the link between debt and economic growth. Previous empirical evidence has found mixed results to support the debtoverhang hypothesis. Chowdhury (2001), Clements, Bhattacharya and Nguyen (2003), Mohamed (2005), Wijeweera, Dollery and Pathberiya (2005) and Sen, Kasibhatla and Stewart (2007) found evidence to support the negative effect of external debt on a country's economic growth. In other words, an increase in the stock of debt has a negative impact on economic growth. Previous empirical works done by Choong, Lau, Liew and Puah (2010) suggest that external debt have a negative effect on Malaysia long-run economic growth. Furthermore, the Granger causality test also reveals the existence of short-run causality linkages between external debt and economic growth. Meanwhile, Pattilio, Poirson and Ricci (2004), Cordella, Ricci and Ruiz-Arranz (2005), and Imbs and Ranciere (2005) found non-linearity in the debt-growth relationship. Furthermore, Patillio, Poirson and Ricci (2004) report that the average impact of debt on per capita growth appears to become negative for debt levels above 160 to 170 percent of exports and 35 to 40 percent of GDP. Clements, Bhattacharya and Nguyen (2003) found that, above the threshold of 20-25 percent of GDP and 101-105 percent of exports, external debt is associated with lower rates of growth for 55 low income countries. However, the study by Schclarek (2004) stands in contrast to the others since there it finds no evidence of non-linearity (inverted- $U$ shape relationship) for selected developing countries.

Meanwhile, the flow of debt, and the debt service of external debt in particular, could affect growth by crowding out private investment or public spending. lyoha (1999) provides evidence of the crowding-out effect in the sub-Saharan African countries, implying that heavy external debt stock and debt service payment could reduce foreign investment into the country. Clements, Bhattacharya and Nguyen (2003) support the crowding-out effect for 55 low-income countries. On the other hand, Pattillio, Poirson and Ricci (2004) found that one third of the effect of debt on growth occurs via physical capital accumulation and two thirds via total factor productivity growth. As such, by extending the analysis to investigate the potential of the nonlinear relationship between external debt and economic growth as well as providing the optimal level of external debt that Malaysia should hold will fill the gap in the literature. 


\section{DATA AND ECONOMETRICS MODEL}

Inspired by the dual-gap theory, Otani and Villanueva (1989), Agenor (2000), Villanueva (2003), and Villanueva and Mariano (2007) developed a theory on the relationship between external debt and economic growth through several mechanisms such as fiscal policy adjustment. This has revealed the role of external debt in contributing to a country's economic growth. On the other hand, Villanueva (2003) has extended the standard neoclassical growth model that incorporates endogenous technical change and global capital market. In addition, Villanueva (2003) defines the aggregate capital stock as the accumulated sum of domestic saving and net external borrowing. As has been explained in the neoclassical growth model, a country that intends to increase its economic growth could increase its saving, which would lead to an increase in investment and, to a lesser extent, economic growth. In addition, Villanueva (2003) claims that economic growth will not increase until capital stock has risen to a certain level. As such, a rise in capital through debt accumulation will result in an increase in saving rate, investment rate and economic growth. Thus, to investigate whether the external debt has contributed to the economic growth, the growth model to be estimated is

$$
y_{t}=\beta+\beta_{1} G R O S S F_{t}+\beta_{2} P O P_{t}+\beta_{3} G R E V_{t}+\beta_{4} O P E N N_{t}+\beta_{5} E D_{t}+\beta_{6} D S E R V_{t}+\varepsilon_{t}
$$

where (at time $t$ ), $y$ is real of Gross Domestic Product (GDP), GROSSF is gross investment, POP is population, GREV is government revenue, OPENNis trade openness, EDis external debt, DSERV is debt service payment and $\varepsilon_{t}$ represent the error term. The basic growth model to be estimated include $y$ (dependent variable) as a proxy of economic growth while the independent variable includes GROSSF, POP, GREV, OPENN, ED and DSERV. The GROSSF and POP represent the rates of growth of factor inputs (capital and labor force) in the production function. Meanwhile, GREV, OPENN and DSERV account for country-specific government policies particularly on the fiscal, trade and debt management policy.

All data are collected from the Monthly Bulletin Statistics issued by Central Bank of Malaysia from the period 1991Q1 to 2009Q4. Since the observations are on a quarterly basis, for maximum order of the lags in the ARDL model, a lag order of 4 is chosen. The Autoregressive Distributed Lag (ARDL) bound test developed by Pesaran, Shin and Smith (2001) is being employed for cointegration analysis. One of the advantages of the Pesaran, Shin and Smith (2001) approach is that this method is robust to small sample sizes (Pattichis, 1999; Mah, 2000; Tang and Nair, 2002). Basically, the bound test developed by Pesaran Shin and Smith (2001) is the Wald test (F-statistic version of the bound testing approaches) for the lagged level variables in the right-hand side of an Unrestricted Error Correction Model (UECM). The asymptotic distribution of the F-statistic is non-standard under the null hypothesis of no cointegrating relationship between the examined variables, irrespective of whether the explanatory variables are purely $\mathrm{I}(0)$ or I(1).

If the statistic from a Wald test falls outside the critical bounds value (lower and upper values), a conclusive inference can be made without considering the order of integration of the explanatory variables. In addition, if the F-statistic exceeds the upper critical bound, the null hypothesis of no cointegrating relationship can be rejected. However, if the test statistic ( $F$ statistic) falls below the lower critical bound, then the null of non-cointegration cannot be rejected. If the F-statistic falls between the upper and lower bounds, a conclusive inference cannot be made. 
The second stage of the ARDL approach is to estimate the coefficients of the long-run cointegrating relationship and the corresponding error correction model. Below is the error correction version of the $\operatorname{ARDL}(p, q, q, q, q)$ model in the variables GDP, GROSSF, POP, OPENN, GREV, ED, DSERV;

$$
\begin{aligned}
& \Delta \operatorname{Ln}(G D P)_{t}=\alpha_{0}+\sum_{i=1}^{p} a_{i} \Delta \operatorname{Ln}(G D P)_{t-i}+\sum_{i=0}^{q} b_{i} \Delta \operatorname{Ln}(G R O S S F)_{t-i}+\sum_{i=0}^{q} c_{i} \Delta \operatorname{Ln}(P O P)_{t-i}+ \\
& \sum_{i=0}^{q} d_{i} \Delta \operatorname{Ln}(O P E N N)_{t-i}+\sum_{i=0}^{q} e_{i} \Delta \operatorname{Ln}(G R E V)_{t-i}+\sum_{i=0}^{q} f_{i} \Delta \operatorname{Ln}(D S E R V)_{t-i}+ \\
& \sum_{i=0}^{q} g_{i} \Delta \operatorname{Ln}(E D)_{t-i}+\delta_{1} \operatorname{Ln}(G D P)_{t-1}+\delta_{2} \operatorname{Ln}(G R O S S F)_{t-1}+\delta_{3} \operatorname{Ln}(P O P)_{t-1}+ \\
& \delta_{4} \operatorname{Ln}(\text { OPENN })_{t-1}+\delta_{5} \operatorname{Ln}(G R E V)_{t-1}+\delta_{6} \operatorname{Ln}(D S E R V)_{t-1}+\delta_{7} \operatorname{Ln}(E D)_{t-1}+e_{t}
\end{aligned}
$$

The lagged error correction term $\left(e_{t-1}\right)$ derived from the error correction model is an important element in the dynamics of the cointegrated system as it allows for adjustment back to the long-term equilibrium relationship given a deviation from the last year.

In addition, this paper also tries to examine the existence of the threshold effect which made it possible to estimate the optimal amount of external debt holding. Thus, the test proposed by Hansen (2000) to assess the null hypothesis of a linear regression against a threshold regression analysis has been employed. In the form of the thresholds model,

$$
\begin{aligned}
& y_{t}=\beta_{1}^{\prime} x_{t}+\mu_{t} q_{t} \leq \gamma \\
& y_{t}=\beta_{2}^{\prime} x_{t}+\mu_{t} q_{t}>\gamma
\end{aligned}
$$

where $q_{t}$ is the threshold variable, which is external debt $E D$. The threshold variable could be part of the regressors and it is used to split the sample into two regimes. Meanwhile $y_{t}$ is economic growth measured by real gross domestic product (GDP). $x_{t}$ is $p \times 1$ vector of independent variables and $\mu_{t}$ is a regression error. Models (3) and (4) can be written in a single equation form as

$$
y_{t}=\beta^{\prime} x_{t}+\theta x_{t}(\gamma)+\mu_{t}
$$

where $d_{t}=I\left(q_{t} \leq \gamma\right)$ where $I($.$) denotes the indicator function and sets the variable$ $x_{t}(\gamma)=x_{t} d_{t}(\gamma)$. Furthermore, the null hypothesis of linearity against a threshold specification can be expressed as:

$$
H_{0}: \beta_{1}=\beta_{2}
$$

Hansen (2000) has developed a threshold model estimator which considered the least squares estimations. In addition, by providing an asymptotic simulation test of the null of linearity against the alternative of a threshold, this method also computed a confidence interval by inverting the likelihood ratio statistics. Hansen (2000) also proposes an F-test bootstrap (heteroskedasticity-consistent) procedure to test the null of linearity. Since the threshold value 
$\gamma$ is not identified under the null, the $\mathrm{p}$-values are computed by a fixed bootstrap method. The independent variables are supposed to be fixed and the dependent variable is generated by a bootstrap from distribution $N(0, \hat{\mu})_{i}$, where $\hat{\mu}_{i}$ is the OLS residual from the estimated thresholds model. In other words, it is estimated by fixing the regressors at the right-hand side and generating the bootstrap dependent variable from the dependent variable. Hansen (2000) shows that this procedure yields asymptotically correct $p$-values. If the null hypothesis of linearity is rejected, one can split up the original sample according to the estimated thresholds value and perform the same analysis on each subsample. The distribution of the threshold estimator is nonstandard while it only allows one threshold relationship and one threshold variable. The method is employed for this analysis to examine the optimal level of external debt that a country should hold. In addition, with continuous variables such as GDP and ED used in this analysis, this method developed by Hansen (2000) is the most relevant for use in this study.

\section{RESULTS AND DISCUSSION}

Table 2 presents the result of the F-statistic for testing the long-run relationship between external debt and economic growth. ${ }^{4}$ To provide additional insight into the debt-growth relationship, this paper also estimates the model for the periods 1991Q1 to 1997Q3 and 1998Q3 to 2009Q4. ${ }^{5}$ The computed F-statistic's value of 3.8774 exceeds the critical bound ( 2.476 to 3.646 ) at the 5 percent significance level when the maximum lag order of 4 is imposed for the overall period. This implies that the null hypothesis of no cointegrating long-run relationship can be rejected. The evidence of a long-run relationship rules out the possibility of any spurious relationship existing between the variables. In other words, there is a theoretical relationship existing between the variables. Furthermore, the estimated F-statistics of 24.8089 and 3.6000 for the periods of 1991Q1 to 1997Q3 and 1998Q3 to 2009Q4 respectively exceed the critical bound (at 5 percent significance leveland 10 percent significance level respectively), indicating the existence of a long-run cointegration relationship of the debt-growth model. Thus, these results confirmthe robustness of evidence on the existence of a long-run relationship between GDP and external debt in Malaysia.

\footnotetext{
${ }^{4}$ Unit root test has been conducted to confirm the non-existence of $\mathrm{I}(2)$ variables. The results found that all variables are non stationary variables, I(1) variables.

${ }^{5}$ It has been noted that Malaysia experienced the Asian financial crises in 1997. The economy started to recover after the pegged exchange rate (with United States dollar) policy was announced by the Central Bank of Malaysia in September 1998.
} 
TABLE 2 - F-STATISTICS FOR TESTING THE EXISTENCE OF LONG-RUN RELATIONSHIP

\begin{tabular}{lccc}
\hline \hline & Overall period & 1991Q1-1997Q3 & 1998Q3-2009Q4 \\
\hline Test statistics & $3.8774^{*}$ & $24.8089^{*}$ & $3.6000^{* *}$ \\
$\begin{array}{l}\text { Critical value at 5 percent } \\
\text { Lower bound, Upper bound }\end{array}$ & $2.476,3.646$ & $2.476,3.646$ & $2.476,3.646$ \\
Critical value at 10 percent & & & \\
Lower bound, Upper bound & $2.141,3.250$ & $2.141,3.250$ & $2.141,3.250$ \\
\hline \hline
\end{tabular}

Source: Author research

Notes:*and ${ }^{* *}$ denotes significant at 5 and 10 percent significance level respectively. The critical values are provided by Pesaran, Shin and Smith (2001), unrestricted intercept and no trend. All models include intercept in the estimation.

Once a long-run cointegration relationship has been established, the estimates of the ARDL long-run coefficient for the estimated model are presented in Table 3. The external debt variables are found to have a positive and significant (at 5 percent significance level) effect on Malaysia's economic growth. For the overall period from 1991Q1 to 2009Q4, the estimated coefficient of the long-run relationship shows that an increase in external debt contributed to Malaysia's economic growth.

A 1 percent increase in external debt is associated with an increase in economic growth of 0.78 percent. The result also shows a positive relationship between external debt and Malaysia's economic growth for the sub-period analysis of $1998 \mathrm{Q} 3$ to 2009 Q $4 .^{6}$ In other words, the external borrowings are found to improve the country's investment rate and, to a lesser extent, economic growth. Other control variables, such as gross investment, government revenue and population growth, are found to have a positive and significant (at 5 percent significance level) effect in explaining the real GDP level. The result implies that any fluctuation and movement in the gross investment, population, government revenue and external debt are found to be cointegrated with the changes in real GDP. On the other hand, the debt service variable and the trade openness variable are found to have negative and significant (at 5 percent significance level and 10 percent significance level respectively) effect on the economic growth. This indicates that the debt service payments are crowdingout the investment opportunity and economic growth.

The error correction model representation for the ARDL model is based on the Schwarz Bayesian criterion. For the overall period, the error correction term coefficient is estimated at 0.3648 , is statistically significant, and has the correct sign, ensuring that the long-run equilibrium is attainable. This suggests that economic growth is adjusting moderately at 36.48 percent to changes in the explanatory variables before reaching its equilibrium.

\footnotetext{
${ }^{6}$ There is no evidence of the relationship between external debt and economic growth for the sub-period of 1991Q1 to 1997 Q3.
} 
TABLE 3 - RESULTS OF ESTIMATED LONG-RUN COEFFICIENT USING THE ARDL APPROACH

\begin{tabular}{|c|c|c|c|}
\hline GDP & $\operatorname{ARDL}(3,0,0,0,1,0,0)$ & $\operatorname{ARDL}(2,2,2,0,0,2,2)$ & $\operatorname{ARDL}(1,1,0,0,1,0,0)$ \\
\hline & Overall period & \multicolumn{2}{|c|}{ Sub-period } \\
\hline & 1991Q1-2009Q3 & 1991Q1-1997Q3 & 1998Q3-2009Q4 \\
\hline \multirow[t]{2}{*}{ GROSSF } & 0.3153 & -0.1715 & 0.3985 \\
\hline & $(0.0693)^{*}$ & $(0.1074)$ & $(0.1519)^{*}$ \\
\hline \multirow[t]{2}{*}{ POP } & 1.6900 & 5.2901 & 0.6647 \\
\hline & $(0.3256)^{*}$ & $(0.6147)^{*}$ & $(0.5618)$ \\
\hline \multirow[t]{2}{*}{ GREV } & 0.1154 & -0.0711 & 0.0283 \\
\hline & $(0.0411)^{*}$ & $(0.0358)^{* *}$ & $(0.0439)$ \\
\hline \multirow[t]{2}{*}{ OPENN } & -0.5552 & 0.2038 & 0.4630 \\
\hline & $(0.3286)^{* *}$ & $(0.0570)^{*}$ & $(0.0964)^{*}$ \\
\hline \multirow[t]{2}{*}{$\mathrm{ED}$} & 0.7810 & -0.0735 & 0.2726 \\
\hline & $(0.2914)^{*}$ & $(0.0542)$ & $(0.1234)^{*}$ \\
\hline \multirow[t]{2}{*}{ DSERV } & -0.0573 & 0.0213 & -0.0258 \\
\hline & $(0.0255)^{*}$ & $(0.0105)^{*}$ & $(0.0309)$ \\
\hline \multirow[t]{2}{*}{ C } & -11.9512 & -40.763 & -8.3784 \\
\hline & $(2.4828)^{*}$ & $(4.9844)^{*}$ & $(3.5595)^{*}$ \\
\hline \multirow[t]{3}{*}{$E C T_{t-1}$} & -0.3648 & -0.937 & -0.4360 \\
\hline & $(0.0735)^{*}$ & $(0.1380)^{*}$ & $(0.1312)^{*}$ \\
\hline & \multicolumn{2}{|c|}{ ARDL-VECM diagnostic test } & \\
\hline Adjusted R-squared & 0.998 & 0.982 & 0.8256 \\
\hline Serial Correlation $\chi^{2}(4)$ & $0.9266[0.921]$ & $23.608[0.00]^{*}$ & $1.9430[0.746]$ \\
\hline Functional Form $\chi^{2}(1)$ & $2.1124[0.146]$ & $1.1020[0.294]$ & $1.1648[0.280]$ \\
\hline Heteroskedasticity $\chi^{2}(1)$ & $0.0837[0.772]$ & $0.1827[0.669]$ & $1.8542[0.173]$ \\
\hline
\end{tabular}

Source: Author research

Notes: *and ** denotes significant at 5 and 10 percent significance level respectively. GDP is the real gross domestic product, GROSSF is gross investment, POP is population, GREV is government revenue, OPENN is trade openness, ED is external debt, DSERV is debt service payment. The ARDL model is selected based on Schwarz Bayesian Criterion (SBC). The serial correlation test is based on Lagrange multiplier test of residual serial correlation, the functional form test is based the Ramsey's test, and the heteroskedasticity test is based on the regression of squared residuals on squared fitted value. Numbers in parenthesis represents the $p$-value.

Table 3 also provides diagnostic results from the estimated model. Based on the LM test statistics, none of the test statistics could reject the null of no serial correlation, functional form and heteroskedasticity in the model. As such, the models have conceded all the diagnostic tests against functional form misspecification, serial correlation, and heteroskedasticity for the overall (1991Q1 to 2009Q4) and 1998Q3 to 2009Q4 period of analysis. Thus suggest that the estimation for the overall and 1998Q3 to 2009Q4 period of analysis is unbiased and efficient. However, the analysis over the sub-period of 1991Q1 to 1997Q3 rejects the null of no serial correlation (significant chi-square value at 5 percent). Hence, careful interpretation is needed since it suffers from the serial correlation problem.

To provide additional insight that attempts to tease out more detail on the relation between external debts and Malaysia's economic growth, it is useful for policy formulation to analyze the optimal stock of external indebtedness. By employing the threshold method of Hansen (2000), this paper also explores any potential threshold effect in the debt-growth model. By using 10,000 bootstrap replications, the results for F-statistics and the p-value for the threshold model are reported in Table 4.The F-statistics and the bootstrap p-value suggest a 
rejection of the null of no thresholds effect at 5 percent significance level of external debt on economic growth over the period 1991 to 2009.

\section{TABLE 4 - RESULTS OF THRESHOLD REGRESSION}

\begin{tabular}{|c|c|c|c|c|}
\hline & & Overall period & $\begin{array}{l}\text { 1991Q1- } \\
\text { 1997Q3 }\end{array}$ & 1998Q3-2009Q4 \\
\hline \multicolumn{2}{|l|}{ F-test statistics } & 58.207 & 34.809 & 74.9258 \\
\hline \multirow{3}{*}{$\begin{array}{l}\text { Bootstrap } \\
\text { value }\end{array}$} & $\mathrm{p}-$ & $0.000^{*}$ & 0.404 & $0.000^{*}$ \\
\hline & & $q_{i} \leq 170,757.02$ & $q_{i} \leq 73,635$ & $q_{i} \leq 175,874.64$ \\
\hline & & Coefficien & & \\
\hline \multirow[t]{2}{*}{ GROSSF } & & 0.1402 & 0.5419 & -0.0001 \\
\hline & & $(0.0216)^{*}$ & $(0.1019)^{*}$ & $(0.06444)$ \\
\hline \multirow[t]{2}{*}{ POP } & & 0.1362 & -0.2942 & 0.5650 \\
\hline & & $(0.1449)$ & $(0.5702)$ & $(0.2829)^{*}$ \\
\hline \multirow[t]{2}{*}{ GREV } & & 0.1157 & 0.0645 & 0.1140 \\
\hline & & $(0.0321)^{*}$ & $(0.0808)$ & $(0.0326)^{*}$ \\
\hline \multirow[t]{2}{*}{ OPENN } & & 0.2929 & 0.05486 & 0.3472 \\
\hline & & $(0.0379)^{*}$ & $(0.1023)$ & $(0.0711)^{*}$ \\
\hline \multirow[t]{2}{*}{ ED } & & 0.1069 & 0.0830 & 0.1666 \\
\hline & & $(0.0258)^{*}$ & $(0.1164)$ & $(0.1377)$ \\
\hline \multirow[t]{2}{*}{ DSERV } & & 0.0237 & 0.0611 & -0.0066 \\
\hline & & $(0.0201$ & $(0.0366)$ & $(0.0402)$ \\
\hline \multirow[t]{2}{*}{$\mathrm{C}$} & & -0.5424 & 3.1256 & -4.7590 \\
\hline & & (1.1317) & $(4.617)$ & $(3.1172)$ \\
\hline $\begin{array}{l}\text { No } \\
\text { observations }\end{array}$ & of & 73 & 27 & 46 \\
\hline \multirow[t]{3}{*}{ R-Squared } & & 0.988 & 0.94 & 0.930 \\
\hline & & $q_{i}>170,757.02$ & $q_{i}>73,635$ & $q_{i}>175,874.64$ \\
\hline & & Coefficien & & \\
\hline \multirow[t]{2}{*}{ GROSSF } & & 0.0878 & 0.0530 & 0.1050 \\
\hline & & $(0.0387)^{*}$ & $(0.03714)^{*}$ & $(0.0386)^{*}$ \\
\hline \multirow[t]{2}{*}{ POP } & & 0.2628 & 1.4052 & 0.1552 \\
\hline & & $(0.1511)$ & $(0.4096)^{*}$ & $(0.1522)$ \\
\hline \multirow[t]{2}{*}{ GREV } & & 0.0413 & 0.2834 & 0.0407 \\
\hline & & $(0.0089)^{*}$ & $(0.0803)^{*}$ & $(0.0085)^{*}$ \\
\hline \multirow[t]{2}{*}{ OPENN } & & 0.1659 & 0.3614 & 0.1846 \\
\hline & & $(0.0219)^{*}$ & $(0.0615)^{*}$ & $(0.0258)^{*}$ \\
\hline \multirow[t]{2}{*}{ ED } & & -0.0401 & -0.0523 & -0.0129 \\
\hline & & $(0.0249)^{*}$ & $(0.0455)$ & $(0.0209)^{*}$ \\
\hline \multirow[t]{2}{*}{ DSERV } & & -0.0042 & -0.0165 & 0.0031 \\
\hline & & $(0.0077)$ & $(0.0236)$ & $(0.0085)$ \\
\hline \multirow[t]{2}{*}{ C } & & 2.6998 & -12.7828 & 3.1721 \\
\hline & & $(1.1063)^{*}$ & $(3.5795)^{*}$ & $(1.0863)^{*}$ \\
\hline $\begin{array}{l}\text { No } \\
\text { observations }\end{array}$ & of & 73 & 27 & 46 \\
\hline R-Squared & & 0.971 & 0.96 & 0.971 \\
\hline
\end{tabular}

Source: Author research

Notes: *and ** denotes significant at 5 and 10 percent significance level respectively. GROSSF is gross investment, POP is population, GREV is government revenue, OPENN is trade openness, ED is external debt, DSERV is debt service payment. The null hypothesis is no threshold relationship. Number in brackets represents the standard error. 
This indicates the evidence of a threshold effect for the debt-growth model (Pattillo, Poirson and Ricci, 2004; Cordella, Ricci and Ruiz-Arranz, 2005; Imbs and Ranciere, 2005). Intuitively, it shows the existence of an inverted- $U$ shape relationship between the debt stock and growth. The inverted- $U$ relationship explains that an increase in debt stock has a positive effect on economic growth until it achieves the optimal level (up to a certain level). Beyond the threshold level, an increase in stock of indebtedness is associated with negative effects on economic growth. The negative effect could be related to the fact that it has not been efficiently allocated to investment; furthermore, too much debt holding might squeeze the investment through debt repayment. In addition, for the sub-period of 1991Q1 to 1997Q3 the F-statistics could not reject the null of no threshold effect, which implies that, during the period, the relationship between external debt and economic growth is linear. Meanwhile, the null of no threshold effect of external debt and economic growth is rejected for the period 1998Q3 to 2009Q4, suggesting the existence of an inverted- $U$ shape relationship between the debt stock and growth in Malaysia.

In addition, the results show that the threshold estimate of external debt is at RM170,757 million for the overall period estimation. The results also reveal that an increase of external debt below RM170,757 million is associated with an increase in Malaysia's economic growth. This result is slightly lower than the threshold estimates found for the period 1998Q3 to 2009Q4. As the stock of external indebtedness increases, it is associated with a negative effect of external debt on the economy. The empirical results obtained in this study would suggest Malaysia hold external debt within the limit of RM170,757 million and RM175,875 million. Intuitively, with the current stock of external indebtedness of RM233,917 (as at the end of Q4 2009), Malaysia is positioned in the 'bad' section of the "Laffer Curve", which implies that accumulating more borrowings would raise the risk of being trapped in the debt-overhang situation.

\section{CONCLUSION}

This article analyzes whether external debt contributes to Malaysia's economic growth in the long run. By employing the Autoregressive Distributed Lag (ARDL) for the period 1991 to 2009, the study demonstrates the existence of a long-run relationship between GDP and external debt in Malaysia. In addition, the results also show a consistent positive relationship between external debt and Malaysia's economic growth for the subperiod analysis. The main contribution of this study is in proving the optimal stock of external indebtedness by employing the threshold method of Hansen (2000). The results substantiate the notion that the accumulation of external debt is associated with an improvement in Malaysia's economic growth up to a certain optimal point; above that level, an additional rise in external indebtedness contributes inversely to the Malaysian economy. Malaysian policy-makers should play an effective role in monitoring Malaysia's external debt position, and close attention should be given to avoiding the risk of being trapped in the debt overhang situation. In particular, policy-makers should reformulate the external debt management strategy to minimize sovereign risk through diversification of the external borrowing. This could potentially be achieved by reducing the dependency on one specific debt instrument or currency. Hence, the strategy will be effective if it is carried out in parallel with a comprehensive surveillance and debt-monitoring system. 


\section{REFERENCES}

Agenor, Pierre-Richard.The economics of adjustment and growth. London: Harvard University Press, 2000.

Borensztein, Eduardo and Ugo Panizza."The costs of sovereign default." IMF Working Paper08/238, International Monetary Fund, October2008.

Central Bank of Malaysia.Annual Report 2009. Kuala Lumpur: Central Bank of Malaysia, 2009.

Central Bank of Malaysia.Monthly Bulletin, Kuala Lumpur: Central Bank of Malaysia, various issues.

Choong, Chee Keong, Evan Lau, Venus Liew Khim-Sen and Puah Chin-Hong.“Does debtsfoster economic growth? The experience of Malaysia", African Journal of Business Management 4,no. 8 (2010): 1564-1575.

Chowdhury, Abdur R."External debt and growth in developing countries: A sensitivity and causal analysis." World Institute for Development Economics Research Discussion Paper 2001/95, United Nations University, September 2001.

Claessens, Stijn, Enrica Detragiache, Ravi Kanburand Peter Wickham. "HIPC's debt review of the issue",Journal of African Economics 6, no. 2 (1997): 231-254.

Clements, Benedict, Rina Bhattacharya and Toan Quoc Nguyen."External debt, public investment and growth in low-income countries."IMF Working Paper 03/249,International Monetary Fund, December2003.

Cohen, Daniel."Large external debt and (slow) domestic growth: a theoretical analysis", Journal of Economic Dynamics and Control 19, no. 5-7 (1995): 1141-1163.

Cordella, Tito, Luca Antonio Ricci and Marta Ruiz-Arranz. "Debt overhang or debt irrelevance? Revisiting the debt-growth link." IMF Working Paper05/223,International Monetary Fund, December2005.

Gunning, Jan Willem and Richard Mash."Fiscal implications of debt and debt relief: Issue paper", Mimeo, 1998.

Hansen, Bruce E."Sample splitting and threshold estimation",Econometrica68, no. 3 (2000): 575 603.

Imbs, Jean and Romain Ranciere."The overhang hangover." The World Bank Policy Research Working Paper Series3673, The World Bank, August2005.

International Monetary Fund.External debt statistics: Guide for compiler and users. Washington: International Monetary Fund, 2003.

Iyoha, Milton A."External debt and economic growth in sub-Saharan African countries: An econometric study." AERC Research Paper90,African Economic Research Consortium, March 1999.

Krugman, Paul R.“Financing vs. forgiving a debt overhang”,Journal of Development Economics 29 (1988): 253-268.

Mah, Jai S."An empirical examination of the disaggregated import demand of Korea-The case of information technology product",Journal of Asian Economics 11, no.2 (2000): 237-244.

Mankiw, Nicholas Gregory, David Romer and David N. Weil. "A contribution to the empirics of economic growth",Quarterly Journal of Economics 107, no. 2 (1992): 407-437.

Mohamed, Mutasim Ahmed Abdelmawla."The impact of external debts on economic growth: An empirical assessment of the Sudan 1978-2001", Eastern Africa Social Science Research Review21, no. 2 (2005): 53-66. 
Otani, Ichiro and Delano P. Villanueva."Theoretical aspects of growth in developing countries: External debt dynamic and the role of human capital", IMF Staff Paper36, no.2 (1989): $307-$ 342.

Pattichis, Charalambos A."Price and income elasticities of disaggregated import demand: Results from UECMs and application",Applied Economics31, no. 9, (1999): 1061-1071.

Pattillo, Catherine, Helene Poirson and Luca Ricci."External debt and growth.” IMF Working Paper 02/69, International Monetary Fund, April2002.

Pattillo, Catherine, Helene Poirson and Luca Ricci."What are the channels through which external debt affects growth?"IMF Working Paper04/15, International Monetary Fund, January2004.

Pesaran, M. Hashem, Yongcheol Shin and Richard J. Smith."Bounds testing approaches to the analysis of long-run relationships",Journal of Applied Econometrics16, no. 3(2001): 289-326.

Sandleris, Guido. "Sovereign default: Information, investment and credit",Journal of International Economics 76, no. 2(2008): 267-275.

Schclarek, Alfredo."Debt and economic growth in developing and industrial countries."Lund University Working Paper 34, December 15, 2004.

Sen, Swapan, Krishna M. Kasibhatla and David B. Stewart."Debt overhang and economic growth-The Asian and the Latin America experiences",Economic Systems 31, no. 1(2007): 311.

Solow, Robert M.“A contribution to the theory of economic growth", Quarterly Journal of Economics70, no. 1(1956): 65-94.

Swan, Trevor W. “Economic growth and capital accumulation”, Economic Record 32, no. 2(1956): 344-361.

Tang, Tuck Cheong and Mahendhiran Nair."A cointegration analysis of Malaysian import demand function: Reassessment from the bound test",Applied Economics Letters 9, no. 5 (2002): 293-296.

Villanueva, Delano P.“External debt, capital accumulation and growth.” SMU-SESS Discussion Paper Series in Economics and Statistics, 2003.

Villanueva, Delano P. and Roberto S. Mariano. "External debt, adjustment and growth."In Fiscal Policy and Management in East Asia, edited byTakatoshi Ito and Andrew K. Rose, 199-221. Cambridge: University of Chicago Press, 2007.

Wijeweera, Albert, Brian Dolleryand Palitha Pathberiya."Economic growth and external debt servicing: A cointegration analysis of Sri Lanka 1952 to 2002." Working Paper Series in Economics 8, University of New England, 2005. 


\title{
UTJEČE LI VANJSKI DUG NA EKONOMSKI RAST MALEZIJE?
}

\begin{abstract}
SAŽETAK
Uloga vanjskog duga u ekonomskom rastu je ispitana s obzirom na visoki broj neizvršenih novčanih obaveza, smanjeni ekonomski rast i visoku razinu siromaštva. Stoga, ovaj rad analizira utjecaj vanjskog duga na ekonomski rast Malezije. Kako bi se istražilo je li vanjski dug utjecao na ekonomski rast dugoročno gledano, model rasta je testiran primjenom ARDL graničnog testa. Pored toga, postojanje efekta praga je ispitano kako bi se procijenila optimalna razina vanjskog duga. Empirijski rezultati otkrivaju da je akumulacija vanjskog duga povezana s povećanjem malezijskog ekonomskog rasta na optimalnu razinu dok je dodatno povećanje vanjske zaduženosti preko tog nivoa inverzno pridonijelo malezijskoj ekonomiji.
\end{abstract}

Ključne riječi: ekonomski rast, međunarodna ekonomija, vanjski dug, Malezija 
Siti Nurazira Mohd Daud, Abd Halim Ahmad, W.N.W. Azman-Saini

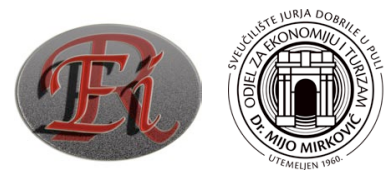

